\title{
Thermal Insulation Materials: A Tool for Energy Conservation
}

Gajanan Deshmukh*, Preeti Birwal, Rupesh Datir and Saurabh Patel

ICAR-National Dairy Research Institute, SRS, Bangalore, India

\begin{abstract}
Energy conservation is an increasingly important issue for the dairy and food industry. Therefore, attention towards thermal insulation systems for plant equipment has grown in recent years. Thermal insulation is the reduction of heat transfer (the transfer of thermal energy between objects of differing temperature) between objects in thermal contact or in range of radiative influence. In this study, a literature review on different thermal insulation material with their properties, types and applications. The selection of optimal thermal insulation has great potential towards the energy saving.
\end{abstract}

\section{Keywords: Energy; Insulation materials}

\section{Introduction}

Insulation materials are very basic and important requirement in any industry dealing with various heat transfer unit operations. It is very important in dairy and food industry to maintain the temperature of chilled water and steam supply, store the products at low temperature either in cold storages or in tanks and transportation of the products at lower temperature. The basic aim of insulation is to retard the rate of heat flow in order to prevent/minimize the change of temperature of the system or the space. It has been reported that in dairy industry $50 \%$ of the energy is consumed in heating and cooling of milk [1]. As dairy and food industry involves several unit operations, either at higher temperature or lower temperature as compared to ambient conditions of the air, the use of insulation materials in dairy and food industry is inevitable for the conservation of energy. There are several insulation materials available in the market having different insulating properties. It is very important to select right type of insulation material considering temperature of the system and mode of heat transfer involved. The selection of insulating material, deciding the thickness, correct method of performing the insulation of steam and chilled water pipelines, milk storage tanks, silos, bulk milk coolers, cold storages, etc. are some of the important considerations to achieve optimum results.

\section{Thermal insulation}

Thermal insulation is defined as a material or combination of materials which on application retards the flow of heat and adapted to any size, shape and surface $[2,3]$. Thus, the insulation is the outcome of performing the process to thermally isolate the system using insulating materials to reduce the heat transfer rate drastically between the system and the adjacent body or the environment. The term 'thermal insulation' is applied in the temperature range from $-75^{\circ} \mathrm{C}$ to $815^{\circ} \mathrm{C}$ and applications below $-75^{\circ} \mathrm{C}$ are termed 'cryogenic' while above $815^{\circ} \mathrm{C}$ are termed as 'refractory' [4].

A thermal insulator is a poor conductor of heat having very low thermal conductivity. Insulation is used in dairy and food industries to prevent heat loss or heat gain. Such materials are porous, containing large number of air cells [5]. Glass wool, polystyrene and polyurethane foam are widely used as insulating materials in dairy and food plants. However, there are few other types of insulation materials which are available as a potential option as an insulating material for dairy and food industry.

\section{Advantages of insulation}

The primary purpose of insulation is to prevent/minimize thermal energy losses for the conservation of energy. However, insulation helps in several ways as indicated below;

I. It provides more accurate control of process temperatures and protection of the product.

II. It prevents condensation on cold surfaces and the resulting corrosion.

III. It helps in saving of energy and reduction in Green House Gases (GHGs) in environment.

IV. It minimises the formation of condensate in steam pipeline and related problems.

\section{It provides fire protection and absorbs vibration.}

Many direct and indirect advantages of insulation have been reported [4,6]. Thermal insulation delivers lots of benefits like; reducing over-all energy consumption, better process control by maintaining process temperature, prevents corrosion, provides fire protection and absorbs vibration [4]. Enhanced thermal protection is the most cost-effective way to reduce energy loss and operational costs [7]. Substantial quantity of heat energy is wasted in industrial plants nationwide because of uninsulated, under maintained or under insulated heated or cooled surfaces [2]. Properly designed and installed insulation systems reduce the consumption of energy. Some recent studies demonstrated that application of thermal insulations may result heating and cooling energy savings up to $25 \%$ [8,9]. Some reports also inferred that, insulation materials have the potential to reduce energy consumption between 18-34\% depending upon the type of insulation and the ambient temperature [10].

\section{Important properties of insulation materials}

There are many properties of insulating materials which are important to consider for the selection of insulation materials from the market. The final selection not only depends on the properties of the material but on the basis of economics and structural considerations.

*Corresponding author: Gajanan Deshmukh, ICAR-National Dairy Research Institute SRS, Bangalore, India, Tel: +91-184-2259008; E-mail: gajanannnn@gmail.com

Received March 21, 2017; Accepted April 11, 2017; Published April 17, 2017

Citation: Deshmukh G, Birwal P, Datir R, Patel S (2017) Thermal Insulation Materials: A Tool for Energy Conservation. J Food Process Technol 8: 670. doi: 10.4172/2157-7110.1000670

Copyright: (c) 2017 Deshmukh G, et al. This is an open-access article distributed under the terms of the Creative Commons Attribution License, which permits unrestricted use, distribution, and reproduction in any medium, provided the original author and source are credited. 
An ideal insulating material should fulfil a number of criteria such as low thermal conductivity, non corrosive, non toxic, non flammable and exhibit little or no decomposition at long period of time [11]. The five key properties of an insulating material to be considered have been described; these properties are compressive strength, service temperature range, thermal conductivity, water absorption and thickness tolerance $[2,3,12]$. The compressive strength of most insulating materials decreases as temperature increases and therefore it is necessary to consider the compressive strength at the service temperature. The service temperature is the highest temperature at which the insulation material can perform reliably in long-term application. Thermal conductivity $(\mathrm{K})$ is the most important in determining a material's ability to resist the flow of heat. The absorption of water in insulating material increases conductivity of the material and causes swelling of the material. Thickness tolerance is important for achieving alignments and product quality. A low value of thermal expansion at operating temperatures is required for the insulation.

\section{Types of insulation materials}

Insulation is well known to humans from a long time. Egyptians used earth as an insulator for their comfort [13]. The first use of insulation using cellulose was patented in England in 1893. It is reported that more applications of insulation started from the 1920's [14].

There are three types of insulation materials in general [3]:

a. Fibrous insulations (e.g. Ceramic fibre, glass mineral wool, rock mineral wool, etc.)

b. Cellular insulations (e.g. Polyurethane, polystyrene and polypropylene, etc.)

c. Granular insulations (e.g. Calcium silicate, perlite expanded and vermiculate)

There are many insulation materials available for hot and cold insulations in dairy and food industry. The following are the insulation materials that are accepted by the process industries [15].

\section{Hot insulation materials}

Glass mineral wool: Glass mineral wool is available in a wide range of forms ranging from flexible rolls, rigid slabs and preformed pipe sections. It is particularly suitable for thermal insulation in steam pipeline, hot water line and other industrial applications such as high performance insulation in the aircraft industry [16]. It is generally used for high temperature insulations as it is cost effective and steady in performance. It is popular in dairy and food industry for steam pipeline insulation. The thermal conductivity is 0.031 to $0.042 \mathrm{~W} /$ $\mathrm{mK}$. The density of the insulation material ranges from 10 to $80 \mathrm{~kg} / \mathrm{m}^{3}$ with service temperature range of $-200^{\circ} \mathrm{C}$ to $450^{\circ} \mathrm{C}$. The compressive strength of the glass mineral wool is 1 to $8 \mathrm{kN} / \mathrm{m}^{2}$, the water vapour transmission is 346 to $417 \mu \mathrm{gm} / \mathrm{Nh}$ and it is non-combustible by nature, which is acceptable for high temperature applications [17].

Cellulose glass: Cellulose glass as an insulating material is available with relatively high density and 40 to $160 \mathrm{~mm}$ thickness. The thermal conductivity ranges from 0.034 to $0.081 \mathrm{~W} / \mathrm{mK}$ with the service temperature of $-260^{\circ} \mathrm{C}$ to $430^{\circ} \mathrm{C}$. The water vapour transmission is zero with a compressive strength of $700 \mathrm{kN} / \mathrm{m}^{2}$. It is a non-combustible insulation material [18].

Calcium silicate: It is suitable to use in superheated steam lines and hot water pipe lines, fitments and vessels. It is also used in furnace insulation or in boiler insulation. It is generally available in $240 \mathrm{~kg} /$ $\mathrm{m}^{3}$ density and a thickness ranging from 25 to $100 \mathrm{~mm}$. The thermal conductivity range is $0.054 \mathrm{~W} / \mathrm{mK}$. The maximum service temperature of calcium silicate is $1000^{\circ} \mathrm{C}$ with no water vapour penetration under normal conditions. It is a non-combustible material and has a compressive strength of $600 \mathrm{kN} / \mathrm{m}^{2}$ [19].

Ceramic fibre: Ceramic fibre is a refractory grade material suitable for use up to $1400^{\circ} \mathrm{C}$. It is generally used for thermal insulation within dairy and food processing industries such as in boilers. The density of the Ceramic Fibre is in the range of 64 to $192 \mathrm{~kg} / \mathrm{m}^{3}$ with a thickness of 6 to $50 \mathrm{~mm}$. The thermal conductivity is from 0.030 to $0.079 \mathrm{~W} / \mathrm{mK}$ with the water vapour transmission of zero. The compressive strength $2.5 \mathrm{kN} / \mathrm{m}^{2}$ and they are non-combustible [15].

Melamine foam: Melamine foam involves a fibre free insulation, suitable for use on low and medium temperature heating. It has applications in food processing, breweries and pharmaceutical industries. Melamine foams are commercially available with $11 \mathrm{~kg} /$ $\mathrm{m}^{3}$ density and 10 to $50 \mathrm{~mm}$ thickness. The thermal conductivity is $0.034 \mathrm{~W} / \mathrm{mK}$ with the service temperature range of $10^{\circ} \mathrm{C}$ to $150^{\circ} \mathrm{C}$. Melamine foams have the water vapour transmission of $350 \mu \mathrm{gm} / \mathrm{Nh}$ and a compressive strength of 5 to $20 \mathrm{kN} / \mathrm{m}^{2}$. The melamine foams are combustible [20].

Perlite expanded: Perlite expanded can be used as structural insulation in cold stores and for storage tanks. It is suitable for use above $180^{\circ} \mathrm{C}$ as it contains no organic materials and can be used insulating refractory materials. Perlite expanded is available with the density of 80 $\mathrm{kg} / \mathrm{m}^{3}$ and of 25 to $300 \mathrm{~mm}$ thickness. It has a thermal conductivity of $0.057 \mathrm{~W} / \mathrm{mK}$. The service temperature range of the perlite expanded is $-250^{\circ} \mathrm{C}$ to $1000^{\circ} \mathrm{C}$ and it is a non-combustible insulating material [15]. Since it contains a hydrophobic agent, it repels water which confirms a zero water vapour transmission rate [21].

Rock mineral wool: Rock mineral wool is used as a thermal insulation and fire protection of plant, equipment and in structures in the commercial and industrial sectors. It has density of $80 \mathrm{~kg} / \mathrm{m}^{3}$ with 20 to $120 \mathrm{~mm}$ thickness. It also has thermal conductivity of $0.033 \mathrm{~W} /$ $\mathrm{mK}$ and a service temperature range of $-200^{\circ} \mathrm{C}$ to $900^{\circ} \mathrm{C}$. It has the water vapour transmission rate of 385-400 $\mu \mathrm{gm} / \mathrm{Nh}$ and a compressive strength of 7.5 to $10.5 \mathrm{kN} / \mathrm{m}^{2}$, which is significantly higher than other insulating materials. It is non-combustible insulating material [16].

Vermiculate: Vermiculate is used as a loose fill granular insulate. It is used in hazardous goods packaging, insulating concretes and with plasters. Sometimes it contains asbestos in it which is not suitable for human health. It is used as both, for general purpose and for fire resistivity. It is used to insulate fitments like steam pipe line as it can bear a high level of vibration. Vermiculate has the density ranging from 50 to $150 \mathrm{~kg} / \mathrm{m}^{3}$ with a thermal conductivity of 0.066 to $0.083 \mathrm{~W} / \mathrm{mK}$. The service temperature range is from $0^{\circ} \mathrm{C}$ to $1300^{\circ} \mathrm{C}$ with a water vapour transmission of Vermiculate is $350 \mu \mathrm{gm} / \mathrm{Nh}$. The thickness range varies according to the use. Vermiculate are non-combustible [22].

\section{Cold insulation}

Cork: Cork is a resilient material and it is suitable for use on chilled water and industrial refrigeration pipe work, as it involves higher vibrations. Oak wood is generally used in cork. It is available with 112 $\mathrm{kg} / \mathrm{m}^{3}$ density and a thermal conductivity of $0.038 \mathrm{~W} / \mathrm{mK}$. Corks have a service temperature range of $-180^{\circ} \mathrm{C}$ to $100^{\circ} \mathrm{C}$. It has water vapour transmission of 20 to $40 \mu \mathrm{gm} / \mathrm{Nh}$ and a very less compressive strength compared to other materials. Corks are available in Slabs and Pipe insulation form with available thickness of 13 to $305 \mathrm{~mm}$. Corks are highly combustible [22]. 
Nitrile rubber expanded: Nitrile rubber expanded is a closed cell, flexible integral vapour barrier insulation. It is widely used for condensation control and reducing heat gain on air conditioning, chilled water and refrigeration services. It is also used for frost protection and energy conservation in chilled water pipe work. Nitrile rubber expanded is having a density of 60 to $90 \mathrm{~kg} / \mathrm{m}^{3}$ with thickness of 6 to $32 \mathrm{~mm}$. Its thermal conductivity ranges from 0.033 to $0.044 \mathrm{~W} / \mathrm{mK}$ with a service temperature of $-40^{\circ} \mathrm{C}$ to $116^{\circ} \mathrm{C}$. This type of insulation materials permits around $0.25 \mu \mathrm{gm} / \mathrm{Nh}$ water vapour transmission. The compressive strength of nitrile rubber expanded is 14 to $35 \mathrm{kN} / \mathrm{m}^{2}$ and they are combustible by nature [20].

Phenolic foam: Phenolic foam is used in commercial and industrial insulation applications where high insulation standards are required but space is less. It can also work as a substitute for PUF in low temperature applications like cold stores and storage tanks. Phenolic foams are having a density range from 35 to $120 \mathrm{~kg} / \mathrm{m}^{3}$ with a thickness of around 10 to $600 \mathrm{~mm}$. The thermal conductivity of this material is between 0.018 to $0.022 \mathrm{~W} / \mathrm{mK}$ and the service temperature range is from $-180^{\circ} \mathrm{C}$ to $120^{\circ} \mathrm{C}$. It has a water vapour transmission of $10 \mu \mathrm{gm} /$ $\mathrm{Nh}$ with a compressive strength of $172 \mathrm{kN} / \mathrm{m}^{2}$. Phenolic foams are noncombustible $[23,24]$.

Polyethylene foam: Polyethylene foams are closed cell insulation materials, refinements to cell structure have made to improve thermal conductivity. It is widely used in the form of pipe insulation for frost protection and energy conservation. Polyethylene foams are available with a density of 30 to $60 \mathrm{~kg} / \mathrm{m}^{3}$ and a thickness range of 6 to $32 \mathrm{~mm}$. The thermal conductivity of polyethylene foam is from 0.033 to 0.045 $\mathrm{W} / \mathrm{mK}$ with the service temperature range of $-50^{\circ} \mathrm{C}$ to $105^{\circ} \mathrm{C}$. The water vapour transmission from this insulation material is $0.5 \mu \mathrm{gm} / \mathrm{Nh}$ and the compressive strength is between 19 to $168 \mathrm{kN} / \mathrm{m}^{2}$ which are higher than some other insulation materials. That is why this type of insulation material is not used where the operating pressure is higher. Polyethylene foams are combustible by nature [5].

Polypropylene: Polypropylene is used for thermal insulation in tank container industry where a lightweight product with low water absorption rate is required. The higher density gives improved mechanical properties and lower thermal conductivity at low temperatures. These types of insulations are widely used in rail or road containers' insulation. Polypropylene is one of the widely used insulation material. It is available with a density of $20 \mathrm{~kg} / \mathrm{m}^{3}$ and a thickness of 43 and $50 \mathrm{~mm}$ and a thermal conductivity of $0.034 \mathrm{~W} /$ $\mathrm{mK}$. This type of insulation materials are high performance insulators. The service temperature range of polypropylene is from $-40^{\circ} \mathrm{C}$ to $130^{\circ} \mathrm{C}$. The water vapour transmission is around $0.45 \mu \mathrm{gm} / \mathrm{Nh}$ and it is noncombustible insulation material [20].

Polystyrene: Polystyrene is used in construction of floor, wall, and roof insulations in cold stores and industrial premises. It is also used as a pipe insulation material in commercial and industrial refrigeration applications. Polystyrene expanded are popularly known as thermocole. This type of insulation materials are widely used and accepted by every industry for the insulation purpose, as it is very cheap. Polystyrenes are available in form of polystyrene expanded and polystyrene extruded. Polystyrene is generally available in 15 to $30 \mathrm{~kg} / \mathrm{m}^{3}$ density and 5 to 610 $\mathrm{mm}$ thickness with a thermal conductivity of 0.033 to $0.038 \mathrm{~W} / \mathrm{mK}$. The service temperature range of polystyrene is from $-150^{\circ} \mathrm{C}$ to $80^{\circ} \mathrm{C}$ and the water vapour transmission rate is $25 \mu \mathrm{gm} / \mathrm{Nh}$. The compressive strength of polystyrene is $15 \mathrm{kN} / \mathrm{m}^{2}$ and it is highly combustible insulation material [25].
Polyurethane foam (PUF): Polyurethane Foams are also known as PUF. It is used in medium to heavy-duty refrigeration systems to reduce heat gain and provide condensation control and in low temperature tanks of carbon dioxide, propane, etc. Laminated panels of PUFs are used in cold stores and refrigerated vehicles. Polyurethane foams are very popular insulation material it is available with thickness of 10 to $15 \mathrm{~mm}$. It has a density ranging from 35 to $50 \mathrm{~kg} / \mathrm{m}^{3}$ with a thermal conductivity ranging from 0.016 to $0.023 \mathrm{~W} / \mathrm{mK}$. The service temperature range of PUF is in the range of $-180^{\circ} \mathrm{C}$ to $110^{\circ} \mathrm{C}$. PUF has a water vapour transmission of $20 \mu \mathrm{gm} / \mathrm{Nh}$ with a maximum compressive strength of $350 \mathrm{kN} / \mathrm{m}^{2}$. These types of insulation materials are combustible by nature $[26,27]$.

Synthetic rubber expanded: Synthetic rubber expanded is used as closed cell, flexible, integral vapour barrier insulant. Different grades suitable for low temperature applications such as for medium or low temperatures and for low-pressure ammonia lines are available. Synthetic rubber expanded is having a thermal conductivity ranging from $0.038 \mathrm{~W} / \mathrm{mK}$ with a density of $60 \mathrm{~kg} / \mathrm{m}^{3}$. The service temperature range of this insulation material is from $-50^{\circ} \mathrm{C}$ to $150^{\circ} \mathrm{C}$. The water vapour transmission rate of this insulation material is $0.1 \mu \mathrm{gm} / \mathrm{Nh}$ with maximum compressive strength of 14 to $35 \mathrm{kN} / \mathrm{m}^{2}$. The synthetic rubber expanded is available with the thickness of 9 to $25 \mathrm{~mm}$. These types of materials are combustible [15].

\section{Method of Insulation}

There is a basic need for insulation at any surface which is in contact with hot or cold surrounding. To insulate a surface, there are few points that are required to be taken care of like cleaning of surface $[28,29]$ and application of corrosion repellents like chloride, fluorine and magnesium to have least amount of water gain to prevent corrosion [30]. Thompson [31] reported that, each product has a different temperature for storage, according to this temperature, the optimum operating temperature and the type of insulation material and thickness of insulation is selected. The designing is a very important which involves location of the plant, temperature conditions and service conditions [32]. Thickness of insulation is also very important in designing, there is a thickness below which the insulation is insufficient and the loss of heat is more [33] Higher thickness results into higher cost input with a little thermal savings [34,35]. Thus, economical thickness has to be calculated for given insulation material.

The water vapour barriers like bituminous, epoxy and aluminium foils of minimum $0.06 \mathrm{~mm}$ are required on the cold side of the insulation [15,36,37]. Hart and Yarbrough [21] noticed that, once the insulation system started to absorb significant quantities of greater than $2 \%$ volume, the performance might find unsatisfactory. Among all insulation materials, Polyurethane Foam (PUF) is the most commonly used insulation material in diary and food industry. It can be applied through blocks or spray of the foam which hardens instantly for insitu or crevice insulation. PUF contains a viscous cream-colored liquid containing a polyether polyol, a silicone surfactant and a catalyst. Another solution is a dark brown viscous liquid containing diphenylmethane di-isocyanate and higher oligomers of di-isocyanate. When the polyether polyol is mixed with the di-isocyanate, an exothermic reaction occurs, producing polyurethane foam. This foam is either sprayed on the wall or filled into a structure where it makes a rigid structure. Prefabricated polyvinyl sheets are applied on it if it is a sprayed insulation [38-40]. Next step is application of insulation material either in-situ insulation or panel insulation with a glue to the surface in a staggered manner and with a wire mash placed above it for better holding of plaster or tiles [15,39]. 
Citation: Deshmukh G, Birwal P, Datir R, Patel S (2017) Thermal Insulation Materials: A Tool for Energy Conservation. J Food Process Technol 8: 670. doi: $10.4172 / 2157-7110.1000670$

Page 4 of 4

\section{Conclusion}

Insulation is one of the essential requirements for conservation of energy in dairy and food industries as many unit operations involve heating and cooling processes. The saving of energy is not only important to reduce the cost of processing, but also helps in reducing the emission of green house gases in the environment. Increased awareness towards the environment and public health is leading to an integrated evaluation of insulation materials and whilst no one questions their positive action, there is still significant potential for improving their overall performance. There are various types of insulation materials which can be used in dairy industry at several places like cold stores, steam and chilled water pipelines, milk silos and tanks, etc. to save the energy loss. The appropriate insulation must be selected on the basis of temperature, thermal conductivity and other factors that might limit application. The optimisation of insulation considering saving of energy, cost of insulation and its installation is one of the basic requirements to achieve optimum benefit. There is a need to develop more efficient insulating materials in terms of heat transfer, water repellent properties, ease of application, strength, etc. The thickness must be determined for the particular application according to the type and temperature range. Insulation materials not only saves the heat loss and energy, but it also helps to protect the contained structure which makes it an essential input required for dairy and food industry.

\section{References}

1. Barber A, Pellow G (2005) Energy use and efficiency measures for the New Zealand dairy farming industry. Agrilink, New Zealand.

2. Shukla AK (2011) Selection of insulation material.

3. Khandelwal M (2010) Basics about insulations. Nirma industries, Gujarat, India.

4. TIAC (2005) Insulation materials and properties. Thermal insulation association of Canada, Canada.

5. BEE (2012) Insulations and refractory. Bureau of Energy Efficiency, New Delhi, India.

6. Arora D, Domkundwar AV (1973) Thermal insulation for air conditioning systems. Refrigeration and air conditioning, Dhanpat rai and Co, New Delhi, India 21: 1-22.

7. Kosny J, Gawin D (2001) Same simple ideas how to reduce the whole building energy consumption in residential buildings. VIII Conference building physics in theory and practice, Technical University of Lodz, Poland

8. Feustel HE (1995) Simplified numerical description of latent storage characteristics for phase change wallboard. Indoor environmental program, University of California, CA, USA.

9. Tomlinson J, Jotshi C, Goswami D (1992) Solar thermal energy storage in phase change materials. The American Solar Energy Society Annual Conference, Cocoa Beach, FL, USA.

10. Ipsi KW (1998) World congress gavle. CIB, Sweden pp: 1265-1272.

11. Ghoneim AA, Klein SA, Duffie JA (1991) Thermal insulation. Solar Energ 47: 237-242.

12. Sethuram C (2011) Proper selection of insulation material is an art.

13. Albert FB (1933) The evolving house. Technology Press, Cambridge University, MA, USA.

14. Kosny J, Yarbrough DW, Wilkes KE, Leuthold D, Syad A (2005) PCMenhanced cellulose insulation thermal mass in lightweight natural fibers, Oak Ridge National Laboratory, USA.
15. TIASA (2001) Thermal insulations. Association of architectural aluminium manufacturers of South Africa, Lyttelton, SA 1: 2-27.

16. Marker TR, Sarkos CP, Hill RG (2011) Full scale test evaluation of aircraft fue fire burn-through resistance improvement. Federal Aviation administration, USA.

17. Volovirta I, Vinha J (2004) Water vapour permeability and thermal conductivity as a function of temperature and relative humidity. Ashare, USA.

18. Westman MP, Laddha SG, Fifield LS, Kafentzis TA, Simmons KL (2010) Natural fiber composites: A review. United States Department of Energy.

19. Anonymous (2004) Calcium silicate board insulation. Christy refractory, McRee Avenue, St. Louis, MO, USA.

20. Bynum RT (2001) Basics of insulation materials. Insulation handbook, McGrawHill publications, NJ, USA 4: 31-50.

21. Hart GH, Yarbrough DW (2010) Industrial insulation systems: Material Selection Factors. Chemical engineering magazine, Access intelligent publications pp: 1-8.

22. Anonymous (2009) Fact sheet. United States environment protection agency, DC, USA pp: 1-4.

23. Silva SP, Sabino MA, Fernandes EM, Correlo VM, Boesel LF, et al. (2005) Cork properties, capabilities and applications, Internat. Mat Reviews 50: 345-365.

24. Anonymous (2011a) Phenolic foam insulation. European phenolic foam association, Hampshire, GU.

25. Anonymous (2005) Fire behaviour characteristics of thermal insulation materials. LNE publications, Paris, France.

26. Morrison R (1994) Spray polyurethane foam for residential building envelope insulation and air seal. Spray polyurethane foam alliance, USA.

27. Anonymous (1996) Thermal systems insulation procedures. Weber State University, USA.

28. Urban B, Engelmann P, Kossecka E, Kosny J (2011) Arranging insulation for better thermal resistance in concrete and masonry wall systems. $9^{\text {th }}$ Nordic symposium on building physics, USA 3: 1-8.

29. Anonymous (1998) Standard recommended practice: The control of corrosion under thermal insulation and fireproofing materials: A systems approach. NACE Standard Report, Texas, USA.

30. Williums J, Evans $O$ (2010) The influence of insulation materials on corrosion under insulation. NACE International Publications, Texas, USA.

31. Thompson JF (1996) Small scale cold rooms for perishable commodities. Department of Agriculture and Natural Resources, CA, USA.

32. Branz A (2007) Designing quality learning spaces: Heating \& Insulation Ministry of Education, New Zealand.

33. Nicholson JD, Wagg RM (1981) Thermal insulation. The efficient use of steam IPC Sci and Tech Press, England 6: 99-116.

34. Anonymous (2011) Process insulation. Energy, mines and resources, CA, USA.

35. Bhatia A (2012) Insulation audit and the economic thickness of insulation. Continuing education and development Inc, New York, USA.

36. Tyler SR (1964) Thermal design of buildings. John Wiley and Sons, New York, USA.

37. Winnik S (2008) European federation of corrosion: Corrosion-under insulation guidelines. Woodhead publishing limited, Cambridge, GBR.

38. Leduff PK, Mauch J (2005) Science kit for student use: Polyurethane foam Science Kit - Teacher's Guide, SED 695B.

39. Anonymous (2010) The energy code and plaster assemblies. Technical services information bureau, CA, USA.

40. Sivertsen K (2007) Polymer foams. 